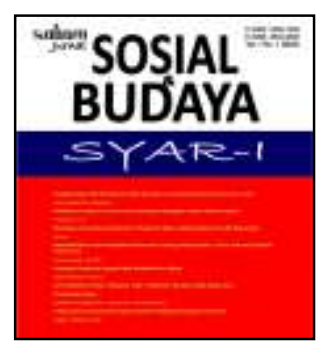

P-ISSN: 2356-1459. E-ISSN: 2654-9050

Vol. 8 No. 5 (2021), pp.1449-1462

DOI: $10.15408 /$ sjsbs.v8i5.22472

http://journal.uinjkt.ac.id/index.php/salam/index

\title{
Tinjauan Yuridis Putusan Constitutional Review Mahkamah Konstitusi Tentang Hak Mantan Narapidana Untuk Menjadi Pejabat Publik Yang Dipilih*
}

\author{
Nanang Nur Wahyudi, ${ }^{1}$ Nynda Fatmawati Octarina ${ }^{2}$ \\ Universitas Narotama Surabaya \\ d. \\ $10.15408 /$ sjsbs.v8i5.22472
}

\begin{abstract}
:
Political rights are protected by law, both internationally and nationally. Internationally, political rights are regulated by the Universal Declaration of Human Rights (UDHR) and the International Covenant on Civil and Political Rights (ICCPR). Political rights are also protected by our constitution and several other laws and regulations, especially Law No. 39 of 1999 concerning Human Rights. There is a provision which is a requirement to run for election which clearly limits and even negates a person's right to participate in exercising their human rights. This is clearly a violation of a person's human rights, which in this case the political rights of an ex-convict, especially in cases of corruption. If we look at the provisions of the 1945 Constitution, an ex-convict is also a citizen who has the same political rights as other citizens. The right to judicial review of regulations that are contrary to the 1945 Constitution, the authority of the right to examine lies with the Constitutional Court (MK). The Constitutional Court's decision provides legal certainty that a former convict in a corruption case is still allowed to run for regional head elections because ex-convicts still have political rights as citizens. To be able to run for regional head elections, ex-convicts after passing through a period of 5 (five) years have finished serving their sentence and have returned to community life as other people's lives. Respect the political rights of ex-convicts of corruption cases as an acknowledgment of human rights in the Republic of Indonesia which are constitutional rights regulated in the 1945 Constitution.
\end{abstract}

Keywords: Prisoners, Judicial Review, Rights, Constitutional Court Decisions

\begin{abstract}
Abstrak:
Hak Politik dilindungi hukum, baik secara internasional maupun nsional. secara internasional, hak politik diatur Universal Declaration of Human Rights (UDHR) dan International Covenant on Civil and Political Rights (ICCPR). Hak politik juga dilindungi konsitusi kita dan beberapa peraturan Perundang-Undangan lainnya, serutama UndangUndang no 39 tahun 1999 tentang Hak Asasi Manusia. Adanya ketentuan yang merupakan syarat untuk mencalonkan diri pada pemilihan yang jelas membatasi bahkan meniadakan hak seseorang untuk ikut serta dalam menggunakan hak azasinya. Hal ini jelas merupakan pelanggaran terhadap hak azasi seseorang, yang dalam hal ini hak politik yang dimiliki oleh seorang mantan narapidana khususnya pada kasus korupsi. Apabila kita mencermati ketentuan UUD 1945, maka seorang mantan narapidana juga sebagai warga negara yang memiliki hak politik yang sama dengan warga negara lainnya. Hak Uji materiel terhadap peraturan yang bertentangan dengan Undang-Undang Dasar 1945, maka kewenangan hak
\end{abstract}

\footnotetext{
* Received: May 03, 2021, Revision: May 25, 2021, Published: September 8, 2021

${ }^{1}$ Universitas Narotama Surabaya. Email: 88nanangnur@gmail.com

${ }^{2}$ Universitas Narotama Surabaya. Email: ninda.fatmawati@narotama.ac.id
} 
menguji ada pada Mahkamah Konstitusi (MK). Putusan Mahkamah Konstitusi memberi kepastian hukum bahwa seorang mantan Narapidana kasus korupsi masih diperbolehkan untuk mencalonkan diri pada pemilihan kepala daerah karena mantan narapidana masih memiliki hak politik sebagai warga negara. Untuk dapat mencalonkan diri pada pemilihan kepala daerah, maka mantan narapidana setelah melewati masa 5 (lima) tahun selesai menjalani masa hukuman dan telah kembali kepada kehidupan masyarakat sebagaimana kehidupan masyarakat lainnya. Menghormati hak politik mantan narapidana kasus korupsi sebagai pengakuan terhadap hak azasi manusia dalam negara Republik Indonesia yang merupakan hak konstitusional yang diatur dalam UUD Tahun 1945.

Kata Kunci: Narapidana, Judisial Review, Hak, Putusan Mahkamah Konstitusi

\section{A. PENDAHULUAN}

Negara Indonesia adalah negara kesatuan yakni kekuasaannya terdiri dari pemerintahan pusat dan pemerintahan daerah. Pemerintahan pusat merupakan kekuasaan yang menonjol dalam negara dan tidak ada saingannya dari badan legislatif pusat dalam membentuk undang-undang. ${ }^{3}$ Pemerintahan daerah adalah Kepala Daerah dan dewan perwakilan rakyat daerah. Kepala Daerah memimpin badan eksekutif dan DPRD bergerak dalam bidang legislatif. Kepala Daerah (Residen, Bupati dan Walikota) adalah pejabat pemerintahan yang diangkat oleh pemerintahan pusat. Mereka masingmasing menurut berbagai peraturan yang berlaku mempunyai tugas menjalankan wewenang pemerintah pusat di lingkungan wilayah jabatannya. ${ }^{4}$

Dalam proses dan kegiatan memilih pejabat publik dalam pemerintahan, dilakukan dengan cara Pemilihan Umum yang melibatkan seluruh rakyat untuk menentukan siapa yang berhak menjadi pejabat publik dalam pemerintahan. Pemilihan ini biasanya disebut Pemilihan Umum atau pemilu. Pemilu merupakan bagian dari proses rakyat yang memilih pemimpin negara. Selain memilih kepala negara sebagai lembaga eksekutif juga memilih DPR sebagai lembaga legislatif dan Kepala Daerah sebagai eksekutif daerah. Pada sistem politik di Indonesia telah mengalami perubahan dalam cara Pemilihan Umum anggota legislatif dan eksekutif yang semula secara perwakilan akhirnya dilakukan secara langsung. Agar dapat diikutkan dalam pemilihan, maka harus mencalonkan diri ke Komisi Pemilihan Umum (KPU) dengan syarat-syarat atau kriteria-kriteria yang telah ditentukan oleh undang-undang.

Dengan adanya syarat tersebut banyak calon yang merasa dirugikan oleh Undang-Undang tersebut. Calon yang merasa dirugikan itu adalah seorang warga negara Indonesia yang ingin mencalonkan diri sebagai calon legislatif (caleg) dalam pemilu 2009, dia bernama Robertus Adji. Karena merasa Undang-Undang berlaku tidak adil pada mantan narapidana (napi), maka dilakukan uji materi terhadap UndangUndang tersebut ke Mahkamah Konstitusi Republik Indonesia.

Pemohon pada uji materi ini adalah Robertus, calon legislator untuk DPRD kabupaten Lahat Sumatra Selatan dari PDI Perjuangan yang gagal karena terganjal kasus pidana. Ia gagal menjadi caleg, karena pernah dipidana selama 9 tahun karena

3 Titik Triwulan Tutik, 2006, Pokok-Pokok Hukum Tata Negara Pasca Amandemen UUD 1945, Prestasi Pustaka, Jakarta, h 283

${ }^{4}$ Ibid, h, 191 
kasus penyimpanan senjata api, perampokan dan penganiayaan berat pada tahun 1976 silam.

Undang-Undang yang diajukan ke Mahkamah Konstitusi untuk diuji materi adalah Undang-Undang Nomor 10 Tahun 2008 tentang Pemilihan Umum DPR, DPD dan DPRD pasal 12 huruf g pasal 50 ayat 1, pasal 58 huruf $f$ Undang-Undang Nomor 12 Tahun 2008 tentang Perubahan Kedua Atas Undang-Undang Nomor 32 Tahun 2004 tentang Pemerintahan Daerah. Menurut pemohon Undang-Undang tersebut tidak memberikan kesempatan kepada mantan narapidana untuk menduduki jabatan legislatif dan Kepala Daerah.

Menurut pakar hukum Universitas Indonesia, Rudi Satriyo Mukantarjo, menilai rumusan yang dihasilkan DPR masih kurang tepat. "Mestinya bukan tidak pernah atau sedang menjalani pidana penjara, tapi sama sekali tidak terlibat dalam kasus pidana". Selain itu banyak kalangan masyarakat yang menganggap Undang-Undang tersebut telah merugikan hak Konstitusional, karena masih memposisikan para terpidana sebagai warga kelas dua karena tidak diberikan kedudukan hukum yang sama. Padahal pada UUD 1945 pasal 27 (1) menyebutkan bahwa "Segala warga negara bersamaan kedudukannya di dalam hukum dan pemerintahan dan wajib menjunjung hukum dan pemerintahan itu dengan tidak ada kecualinya." ${ }^{5}$

Dengan alasan dan berbagai pertimbangan hukum akhirnya Mahkamah Konstitusi mengabulkan bersyarat permohonan pengujian pasal 12 huruf g, pasal 50 ayat (1) Undang-Undang Nomor 10 Tahun 2008 Tentang Pemilihan Umum DPR, DPD dan DPRD dan pasal 58 huruf f Undang-Undang Nomor 12 Tahun 2008 tentang Perubahan Kedua Atas Undang-Undang Nomor 32 Tahun 2004 tentang Pemerintahan Daerah, dengan putusan Mahkamah Konstitusi nomor: 4/ PUU-VII/ 2009.

\section{B. METODE PENELITIAN}

Metode penelitian yang digunakan dalam pembahasan ini adalah metode penelitian Kualitatif dengan pendekatan normatif empiris. Data yang didapatkan bersumber dari buku-buku referensi utama dan kitab-kitab turats, selain merujuk dari beberapa buku dan artikel jurnal lainnya.

\section{HASIL TEMUAN DAN PEMBAHASAN}

1. Kesesuaian Pertimbangan Hukum Majelis Hakim Konstitusi dalam Memutus Constitutional Review Mengenai Hak Narapidana Untuk Dapat Menjadi Pejabat Publik Yang Dipilih (Elected Officials) dengan Konstitusi Negara Republik Indonesia

\section{a. Gambaran Umum Tentang Mahkamah Konstitusi}

Sebelum dilakukan amandemen, Undang-Undang Dasar 1945 (UUD 1945) banyak mengandung kelemahan. Salah satunya adalah tidak tersedianya mekanisme chek and balances, sehingga melumpuhkan kontrol yudisial terhadap pelaksanaan kekuasaan yang sentralistik dan otoriter. Pada akhirnya disadari bahwa untuk

\footnotetext{
${ }^{5}$ UUD 1945
} 
menciptakan pemerintahan yang demokratis yang konstitusional, dibutuhkan lembaga yang memiliki kewenangan untuk melakukan kontrol yudisial terhadap penyelenggaraan negara. Pilihannya jatuh pada Mahkamah Konstitusi. ${ }^{6}$ Mahkamah Konstitusi akhirnya disepakati dibentuk di Indonesia. Bentukan tersebut dilakukan melalui perubahan ketiga Undang-Undang Dasar 1945 (UUD 1945) yang disahkan 10 Agustus 2002. Sejak itu, Indonesia memasuki babak baru dalam kehidupan negaranya yang diyakini akan lebih demokratis dan konstitusional. ${ }^{7}$

Mahkamah Konstitusi dalam sistem ketatanegaraan Indonesia dikatakan sebagai lembaga negara utama (mains state organs, principal organs). UUD 1945 dengan jelas memberikan cabang-cabang kekuasaan negara bidang legislatif, eksekutif dan yudikatif yang tercermin dalam fungsi MPR, DPR dan DPD, Badan Pemeriksa Keuangan (BPK) dan Mahkamah Konstitusi (MK). Lembaga-lembaga negara inilah yang dimaksud secara instrumental mencerminkan pelembagaan fungsi-fungsi kekuasaan negara yang utama, sehingga lembaga-lembaga negara itu pula yang dapat disebut sebagai lembaga negara utama yang berhubungan satu dengan yang lain diikat oleh prinsip chek and balances. $^{8}$

\section{Kewenangan Mahkamah Konstitusi Republik Indonesia (M.K.R.I) Dalam Menguji Undang-Undang Terhadap Undang-Undang Dasar}

Mahkamah Konstitusi merupakan salah satu pelaku kekuasaan kehakiman sebagaimana dimaksud dalam Undang-Undang Dasar Negara Republik Indonesia Tahun 1945. ${ }^{9}$ Keberadaan Mahkamah Konstitusi ini lebih untuk menyelesaikan konflik antar lembaga negara karena dalam proses perubahan menuju negara demokratis tak bisa dihindari munculnya pertentangan antar lembaga negara.

Dalam konteks ketatanegaraan Mahkamah Konstitusi berfungsi menegakkan keadilan konstitusional ditengah kehidupan masyarakat. Kedua, Mahkamah Konstitusi bertugas mendorong dan menjamin agar konstitusi dihormati dan dilaksanakan oleh semua komponen negara secara konsisten dan bertanggung jawab. Ketiga, ditengah kelemahan sistem konstitusi yang ada Mahkamah Konstitusi selalu hidup dan mewarnai keberlangsungan bernegara dan bermasyarakat. Pada hakikatnya fungsi utama Mahkamah Konstitusi adalah mengawal supaya konstitusi dijalankan dengan konsisten dan menafsirkan konstitusi atau UUD. ${ }^{10}$

Mengenai wewenang Mahkamah Konstitusi secara khusus diatur dalam pasal 24 C ayat (1) Undang-Undang 1945 jo pasal 10 ayat (1) Undang-Undang Nomor 24 Tahun 2003 tentang Mahkamah Konstitusi yang menyatakan bahwa Mahkamah Konstitusi berwenang mengadili pada tingkat pertama dan terakhir yang putusannya bersifat final untuk menguji Undang-Undang terhadap Undang-Undang Dasar, memutus sengketa

\footnotetext{
${ }^{6}$ Fathurrahman, Din Aminudin dan Sirojuddi, 2004, Memahami Keberadaan Mahkamah Konstitusi di Indonesia, Bandung, h. 3

${ }^{7}$ Fathurrahman, Din Aminudin dan Sirojuddi, 2004, Memahami Keberadaan Mahkamah Konstitusi di Indonesia, Bandung, h. 3

8 Titik Triwulan Tutik, 2006, Pokok-pokok Hukum Tata Negara, Jakarta, h. 210

${ }_{9}^{9}$ Undang-Undang Nomor 24 Tahun 2003 Tentang Mahkamah Konstitusi, Pasal 1 ayat (1)

${ }^{10}$ Titik Triwulan, 2006, Pokok-pokok Hukum Tata Negara, Jakarta, 2006, h. 163-164
} 
kewenangan lembaga negara yang kewenangannya diberikan oleh Undang-Undang Dasar, memutus pembubaran partai politik dan memutus perselisihan tentang hasil pemilu. ${ }^{11}$

Disamping itu berdasarkan rumusan pasal 24 C ayat (2) UUD 1945 amandemen keempat tanggal 10 Agustus 2002, menyatakan bahwa "Mahkamah Konstitusi wajib memberikan putusan atas pendapat dewan perwakilan rakyat mengenai dugaan pelanggaran oleh presiden dan atau wakil presiden menurut Undang-Undang Dasar."12 Sedangkan dalam pasal 10 ayat (2) Undang-Undang Nomor 24 Tahun 2003 Tentang Mahkamah Konstitusi dijelaskan bahwa: "Mahkamah Konstitusi wajib memberikan putusan atas pendapat dewan perwakilan rakyat bahwa presiden dan atau wakil presiden diduga telah melakukan pelanggaran hukum berupa penghianatan terhadap negara, korupsi, penyuapan, tindak pidana berat lainnya atau perbuatan tercela, dan atau tidak lagi memenuhi syarat sebagai presiden dan atau wakil presiden sebagaimana dimaksud dalam Undang-Undang Dasar Negara Republik Indonesia Tahun 1945. ${ }^{13}$

Berdasarkan ketentuan tersebut maka setiap putusan Mahkamah Konstitusi bersifat final artinya dalam hal pelaksanaan kewenangan ini tidak ada mekanisme banding atau kasasi terhadap putusan yang dibuat Mahkamah Konstitusi untuk perkara-perkara yang berkenaan dengan kewenangan tersebut. Sedangkan kewenangan pada pasal 24 C ayat (2) UUD 1945 jo pasal 10 ayat (2) Undang-Undang Nomor 24 Tahun 2009. Secara khusus UUD 1945 tidak menyatakan Mahkamah Konstitusi sebagai peradilan tingkat pertama dan terakhir yang putusannya bersifat final dan mengikat. Mahkamah Konstitusi hanya diletakkan sebagai salah satu mekanisme yang harus bahkan wajib dilalui dalam proses pemberhentian Presiden dan Wakil Presiden. Kewajiban konstitusional Mahkamah Konstitusi adalah untuk membuktikan dari sudut pandang hukum tidaknya dugaan pelanggaran hukum Presiden dan atau Wakil Presiden. ${ }^{14}$

Mengenai kewenangan untuk menguji Undang-Undang terhadap UUD secara teoritik maupun praktek dikenal ada dua macam yaitu pengujian formal dan pengujian secara materiil. Pengujian secara formal adalah untuk menilai apakah suatu produk legislatif dibuat sesuai prosedur ataukah tidak. Serta apakah suatu kekuasaan berhak mengeluarkan suatu peraturan tertentu.

Dengan kewenangan tersebut MK berhak membatalkan pasal-pasal yang diajukan constitutional review sebab bertentangan dengan UUD 1945 dan karena tidak mempunyai kekuatan hukum yang mengikat lagi. Jadi Mahkamah memperbolehkan mantan narapidana mencalonkan diri untuk menduduki jabatan publik yang dipilih (DPR, DPD, DPRD, dan Kepala Daerah).

\footnotetext{
${ }^{11}$ Mahkamah Konstitusi, Putusan Nomor: 4/PUU-VII/2009 Tentang Pencalonan Mantan Narapidana Sebagai Anggota Legislatif, DPD, Dan Kepala Daerah, Tanggal 28 Januari 2009

12 Undang-Undang Dasar 1945, Pasal 24 C ayat (2)

${ }^{13}$ Indonesia, Undang-Undang Nomor 24 Tahun 2003 Tentang Mahkamah Konstitusi, Pasal 10 ayat (2)

14 Titik Triwulan , op.cit, hal.167
} 


\section{Analisa Kesesuaian Antara Pertimbangan Hukum Majelis Hakim Mahkamah Konstitusi Dengan Konstitusi/Undang-Undang Dasar 1945;}

Berikut uraian tentang kronologi perkara hingga munculnya keputusan MK Nomor: 4/PUU-VII/2009 Tentang Pencalonan Mantan Narapidana Sebagai Anggota Legislatif, DPD, Dan Kepala Daerah. Mengenai masalah pemilihan calon anggota legislatif dan calon kepala daerah, memang menjadi pembicaraan hangat dalam pemilihan tahun 2009. Karena calon anggota legislatif dan calon Kepala Daerah disinyalir telah banyak melakukan pelanggaran-pelanggaran dalam pemilu.

Dalam pemilu Tahun 2009 ada beberapa calon anggota legislatif dan calon Kepala Daerah yang dikeluarkan dari daftar pemilu karena tidak memenuhi salah satu syarat yang telah ditentukan, yaitu:

1. Pasal 12 huruf g Undang-Undang Nomor 10 Tahun 2008 tentang Pemilihan Umum DPR, DPD dan DPRD

2. Pasal 50 ayat 1 huruf g Undang-Undang Nomor 10 Tahun 2008 tentang Pemilihan Umum DPR, DPD dan DPRD

3. Pasal 58 huruf $\mathrm{f}$ Undang-Undang Nomor 12 Tahun 2008 tentang Perubahan Kedua Atas Undang-Undang Nomor 32 Tahun 2004 tentang Pemerintahan Daerah.

Dengan adanya ketentuan yang membatasi berupa persyaratan calon anggota legislatif (DPR, DPD, DPRD) serta calon Kepala Daerah dan Wakil Kepala Daerah bagi mantan terpidana dengan ancaman hukuman 5 (lima) tahun atau lebih jelas-jelas merugikan konstitusional pemohon yang setiap periodesasi ketatanegaraan dengan keadaan normal atau kondisi tertentu akan dilakukan pengisian jabatan tersebut, sehingga hak konstitusional pemohon dapat dipastikan dirugikan dengan adanya persyaratan tersebut.

Dalam penjelasan permohonan, pemohon dalam perkara Nomor: 4/ PUU.VII/2009 mengatakan kepada Majelis Hakim Konstitusi dengan menyatakan. Pertama, pasal 12 huruf g dan pasal 50 ayat (1) huruf g Undang-Undang Nomor 10 Tahun 2008 tentang Pemilihan Umum DPR, DPD dan DPRD serta pasal 58 huruf $\mathrm{f}$ Undang-Undang Nomor 12 Tahun 2008 tentang Perubahan Kedua Atas UndangUndang Nomor 32 Tahun 2004 tentang Pemerintahan Daerah yang kesemuanya mensyaratkan: "tidak pernah dijatuhi pidana penjara berdasarkan putusan pengadilan yang telah mempunyai kekuatan hukum tetap karena melakukan tindak pidana yang diancam dengan pidana penjara 5 (lima) tahun/lebih." Pasal-pasal yang diajukan constitutional review bertentangan dengan UUD 1945 khususnya pasal 1 ayat (2), pasal 27 ayat (1), pasal $28 \mathrm{C}$ ayat (2), pasal $28 \mathrm{D}$ ayat (1) dan ayat (3).

Kedua, menyatakan pasal 12 huruf g dan pasal 50 ayat (1) huruf g UndangUndang Nomor 10 Tahun 2008 tentang Pemilihan Umum DPR, DPD dan DPRD. Serta Pasal 58 huruf f Undang-Undang Nomor 12 Tahun 2008 tentang Perubahan Kedua Atas Undang-Undang Nomor 32 Tahun 2004 tentang Pemerintahan Daerah tidak mempunyai kekuatan hukum yang mengikat. 
Berikut petikan dalil-dalil hukum yang dikemukakan oleh pemohon: ${ }^{15}$

Pertama; Partisipasi Politik yang dipersempit dan status mantan narapidana:

a. Bahwa partisipasi masyarakat merupakan aspek penting dalam suatu pemilihan jabatan, baik yang bersifat jabatan publik yang dipilih seperti pemilihan umum anggota DPR, DPD, dan DPRD, Kepala Daerah dan Wakil Kepala Daerah serta Presiden dan Wakil Presiden, ataupun jabatan yang diangkat. Sehingga oleh karena harus dibuka seluas-luasnya karena hak masyarakat atas partisipasi masyarakat merupakan bagian dari hak asasi manusia sebagaimana tertuang dalam pasal 27 ayat (1), pasal $28 \mathrm{C}$ ayat (2), pasal 28D ayat (1), pasal $28 \mathrm{D}$ ayat (3) UUD 1945, pasal 21 Deklarasi Umum Hak Asasi Manusia / Undang-Undang Hak Asasi Manusia Perserikatan Bangsa-Bangsa Tahun 1948 (DUHAM PBB 1948) dan pasal 5 ayat (1), pasal 15, pasal 4 ayat (1) Undang-Undang Nomor 39 Tahun 1999 tentang Hak Asasi Manusia. Bahwa dengan demikian partisipasi politik merupakan hak asasi manusia setiap warga negara untuk dapat berpartisipasi dalam kegiatan bersama untuk turut serta menetapkan tujuan-tujuan dan masa depan negara termasuk menentukan orang-orang yang akan memegang pemerintahan.

b. Bahwa Undang-Undang Nomor 10 Tahun 2008 tentang Pemilihan Umum DPR, DPD dan DPRD (pasal 12 huruf g dan pasal 50 ayat (1) huruf g) dan UndangUndang Nomor 12 Tahun 2008 tentang Perubahan Kedua Atas Undang-Undang Nomor 32 Tahun 2004 tentang Pemerintahan Daerah (pasal 58 huruf f) secara nyata masih membedakan perlakuan terhadap warga negara yang pernah menjalani hukuman dengan warga negara yang tidak pernah dihukum berdasarkan putusan yang telah berkekuatan hukum tetap. Sehingga nampak dengan jelas dan terang di satu sisi pembentuk Undang-Undang menganggap bahwa mantan narapidana adalah orang yang bebas dan bertanggungjawab, dapat aktif dalam pembangunan sebagai warga yang baik dan lain sebagainya namun di sisi lain masih juga menganggap bahwa mantan terpidana adalah orang yang harus dicurigai, tercela, cacat moralnya dan tidak pantas untuk menduduki jabatan public yang dipilih seperti anggota DPR, DPD, dan DPRD ataupun menjadi kepala daerah dan wakil kepala daerah. Dengan demikian bagaimana mungkin seorang mantan terpidana dapat berperan aktif dalam pembangunan baik formal maupun informal jika negara sendiri telah membatasi ruang gerak atau bahkan membunuh hak-hak politik yang telah dimilikinya sejak lahir padahal di satu sisi dia telah membayar lunas semua akibat yang pernah dilakukannya di masa lampau.

c. Bahwa pemohon selain tidak pernah dicabut hak politiknya oleh pengadilan, juga pada prinsipnya telah menjalani hukuman atas tindak pidana yang pernah dilakukannya. Sehingga sudah selayaknya tidak diperlakukan sebagai pendosa seumur hidupnya.

\footnotetext{
${ }^{15}$ Mahkamah Konstitusi, Putusan Nomor: 4/PUU-VII/2009 Tentang Pencalonan Mantan Narapidana Sebagai Anggota Legislatif, DPD, Dan Kepala Daerah,.h.8-22
} 
d. Bahwa tujuan dari pembentukan suatu norma Undang-Undang adalah tercapainya asas kepastian hukum, keadilan dan kemanfaatan. Dengan adanya pasal a quo dalam Undang-Undang Nomor 10 Tahun 2008 tentang Pemilihan Umum DPR, DPD dan DPRD dan Undang-Undang Nomor 12 Tahun 2008 tentang Perubahan Kedua Atas Undang-Undang Nomor 32 Tahun 2004 tentang Pemerintahan Daerah maka keadilan yang dicari oleh dan bermanfaat bagi pemohon tidak tercapai.

Oleh karenanya pemohon berpendapat bahwa pasal 12 huruf g dan pasal 50 ayat (1) huruf g Undang-Undang Nomor 10 Tahun 2008 tentang Pemilihan Umum DPR, DPD dan DPRD serta pasal 58 huruf f Undang-Undang Nomor 12 Tahun 2008 tentang Perubahan Kedua Atas Undang-Undang Nomor 32 Tahun 2004 tentang Pemerintahan Daerah lebih bersifat pengekangan terhadap hak-hak politik warga negara dan melanggar hak asasi manusia sebagaimana di jamin oleh UUD 1945, pasal 27 ayat (1) , asal 28 C ayat (1), pasal 28 D ayat (1), dan ayat (1), serta pasal 21 Deklarasi Umum Hak Asasi Manusia/Undang-Undang Hak Asasi Manusia Perserikatan Bangsa-Bangsa Tahun 1948.

Kedua; Penghukuman dan Stigmatisasi seumur hidup:

a. Bahwa setiap warga negara yang telah menjalani pidana penjara berdasarkan putusan pengadilan yang telah berkekuatan hukum tetap sama artinya dengan warga negara lainnya yang dilahirkan dalam keadaan bersih, bebas, berharkat, dan bermartabat serta sederajat di mata hukum.

b. Bahwa adanya persyaratan sebagaimana yang tersebut dalam pasal 12 huruf $g$ dan pasal 50 ayat (1) huruf g Undang-Undang Nomor 10 Tahun 2008 tentang Pemilihan Umum DPR, DPD dan DPRD, serta pasal 58 huruf f Undang-Undang Nomor 12 Tahun 2008 tentang Perubahan Kedua Atas Undang-Undang Nomor 32 Tahun 2004 tentang Pemerintahan Daerah tidak dapat menjamin atau menghasilkan calon yang lebih berkualitas dan memiliki integritas lebih baik dibanding dengan orang yang pernah menjalani masa hukuman pidana dengan ancaman hukuman 5 (lima) tahun atau lebih. Bahkan sebaliknya, sejarah pun telah membuktikan bahwa orang yang pernah dihukum atau dipidana pun dapat berinteraksi, bergaul, dan diterima masyarakat sampai pada dipilih dipercaya dan menjadi pemimpin bagi mereka seperti yang pernah dialami oleh Bung Karno dan A.M.Fatwa.

c. Bahwa pasal-pasal a quo selain telah menghapus hak politik mantan terpidana juga telah memberi label mantan terpidana sebagai individu yang berbeda dengan individu lainnya yang tidak pernah dipidana, sehingga tidak mendudukannya secara sama di dalam hukum yang pada akhirnya berimbas pula kepada perlakuan yang tidak sama di muka hukum dan pemerintahan.

Ketiga; Inkonsistensi pembentuk Undang-Undang dan diskriminasi

a. Bahwa ketentuan pasal 12 huruf g dan pasal 50 ayat (1) huruf g Undang-Undang Nomor 10 Tahun 2008 tentang Pemilihan Umum DPR, DPD dan DPRD, serta pasal 58 huruf f Undang-Undang Nomor 12 Tahun 2008 tentang Perubahan 
Kedua Atas Undang-Undang Nomor 32 Tahun 2004 tentang Pemerintahan Daerah selain telah membunuh hak politik dan bersifat diskriminatif juga telah nyata merupakan bentuk dari tidak konsistennya pembentuk Undang-Undang dalam menerapkan persyaratan-persyaratan untuk suatu jabatan publik.

b. Bahwa telah nyata ketentuan pasal 12 huruf g dan pasal 50 ayat (4) huruf $g$ Undang-Undang Nomor 10 Tahun 2008 tentang Pemilihan Umum DPR, DPD dan DPRD, serta pasal 58 huruf f Undang-Undang Nomor 12 Tahun 2008 tentang Perubahan Kedua Atas Undang-Undang Nomor 32 Tahun 2004 tentang Pemerintahan Daerah merupakan bentuk diskriminatif dan bertentangan dengan nilai-nilai asasi dari hak dasar manusia yang pada pokoknya merupakan pembatasan hak fundamental dan inkonstitusional.

c. Bahwa dengan lahirnya pasal-pasal a quo selain menimbulkan sikap diskriminasi, melanggar hak asasi dan hak keperdataan warga negara juga bukanlah Undang-Undang pembuatan yang adil, yang dapat menjamin pengakuan dan penghormatan atas hak asasi manusia, nilai-nilai agama dan ketertiban umum dalam suatu masyarakat demokratis sebagaimana yang diperintahkan oleh UUD 1945, khususnya pasal 28 I ayat (5).

Keempat; Pemilu sebagai perwujudan kedaulatan rakyat

a. Bahwa pasal 1 ayat (2) UUD 1945 menegaskan kedaulatan tertinggi berada di tangan rakyat dan prinsip kedaulatan rakyat merupakan prinsip konstitusi yang sangat mendasar dan tidak dapat dikesampingkan.

b. Bahwa hal yang aneh dan tidak berdasar jika negara menghapus hak dipilih mantan terpidana sedang hak memilihnya tidak dihapus, dan lebih aneh dan tidak berdasar lagi jika hak pilih tersebut dihapus tanpa ada kesalahan yang diperbuatnya. Bukankah perbuatan pidana yang pernah dilakukannya telah mendapat penghukuman tersendiri dan ia telah menjalaninya.

c. Bahwa aspirasi rakyat adalah kehendak jaman yang tak terbantah dan tidak dapat dibendung apalagi sampai dihalang-halangi oleh suatu norma yang pada hakikatnya tidak sejalan dengan pasal 28 I ayat (2) UUD 1945, sehingga perlu dilakukan upaya perbaikan aturan seperti apa yang dikehendaki oleh konstitusi dan semangat demokrasi.

d. Bahwa dengan demikian adanya pasal-pasal a quo selain telah mengenyampingkan rakyat juga bukanlah sebuah Undang-Undang yang adil, yang dapat menjamin pengakuan dan penghormatan atas hak asasi manusia, nilai-nilai agama dan ketertiban umum dalam suatu masyarakat demokratis sebagaimana yang diperintahkan UUD 1945, khususnya pasal 28 J ayat (2).

Sebelum pada akhirnya Mahkamah Konstitusi mengeluarkan putusan Nomor: 4/PUU-VII/2009, sudah pasti mempunyai beberapa pertimbangan yang benar-benar matang dalam memutus suatu perkara. Dalam perkara ini Mahkamah Konstitusi mempunyai dasar pertimbangan yang dapat disimpulkan sebagai berikut; 
a. Bahwa maksud dan tujuan permohonan adalah mengenai pasal pengujian konstitusional pasal 12 huruf g dan pasal 50 ayat (1) huruf g Undang-Undang Nomor 10 Tahun 2008 tentang Pemilihan Umum DPR, DPD dan DPRD, serta pasal 58 huruf f Undang-Undang Nomor 12 Tahun 2008 tentang Perubahan Kedua Atas Undang-Undang Nomor 32 Tahun 2004 tentang Pemerintahan Daerah.

b. Bahwa Mahkamah Konstitusi mempunyai kewenangan untuk mengadili pada tingkat pertama dan terakhir yang putusannya bersifat final untuk menguji Undang-Undang terhadap UUD, sebagaimana dinyatakan dalam pasal 24 C ayat (1) UUD 1945 jo pasal 10 ayat (1) huruf a Undang-Undang Nomor 24 Tahun 2008 tentang Mahkamah Konstitusi.

c. Bahwa sehingga Mahkamah berwenang untuk memeriksa, mengadili, dan memutus permohonan constitutional review.

d. Bahwa dalam kedudukan hukum (legal standing) pemohon menganggap hak dan kewenangan konstitusionalnya yang diberikan oleh UUD 1945 dirugikan oleh berlakunya suatu undang-undang.

e. Bahwa Mahkamah Konstitusi berpendapat pemohon memiliki kedudukan hukum (legal standing) untuk mengajukan permohonan pengujian pasalpasal yang diajukan constitutional review terhadap UUD 1945.

f. Bahwa pemohon mendalilkan pasal yang diajukan constitutional review tersebut bertentangan dengan UUD 1945 sehingga harus dinyatakan tidak mempunyai kekuatan hukum yang mengikat.

g. Bahwa untuk memperkuat dalil-dalilnya, pemohon mengajukan alat bukti surat (bukti P-1 sampai dengan bukti P-9) juga mengajukan ahli Dr. Mudzakkir, SH., MH. yang memberikan keterangan di sidang pleno pada tanggal 10 Maret 2009.

h. Bahwa dalam putusan Nomor: 14-17/PUU-V/2007 tanggal 11 Desember 2007, mahkamah dalam amar putusannya telah menolak pengujian pasal 58 huruf f Undang-Undang Nomor 12 Tahun 2008 Tentang Perubahan Kedua Atas Undang-Undang Nomor 32 Tahun 2004 Tentang Pemerintahan Daerah, pasal 6 huruf E UU No 23 Tahun 2003 tentang pemilu presiden dan wakil presiden, pasal 18 ayat (1) huruf d Undang-Undang Nomor Mahkamah Konstitusi, pasal 7 ayat (2) huruf d Undang-Undang Nomor 5 Tahun 2004 tentang Mahkamah Agung, dan pasal 13 huruf g Nomor 16 Tahun 2006 tentang Badan Pemeriksa Keuangan.

Berdasarkan pertimbangan atas fakta dan hukum yang telah diuraikan diatas, Mahkamah memutuskan: ${ }^{16}$

1. Menyatakan mengabulkan permohonan Pemohon untuk sebagian

\footnotetext{
${ }^{16}$ Mahkamah Konstitusi, Putusan Nomor: 4/PUU-VII/2009 Tentang Pencalonan Mantan Narapidana Sebagai Anggota Legislatif, DPD, Dan Kepala Daerah,.h. 84
} 
2. Menyatakan Pasal 12 huruf g dan Pasal 50 ayat (1) huruf g Undang-Undang Nomor 10 Tahun 2008 serta Pasal 58 huruf f Undang-Undang Nomor 12 Tahun 2008 bertentangan dengan Undang-Undang Dasar Republik Indonesia Tahun 1945 secara bersyarat (conditionally unconstitutional)

3. Menyatakan Pasal 12 huruf g dan Pasal 50 ayat (1) huruf g Undang-Undang Nomor 10 Tahun 2008 serta Pasal 58 huruf f Undang-Undang Nomor 12 Tahun 2008 tidak mempunyai kekuatan hukum mengikat sepanjang tidak memenuhi syarat-syarat, yaitu:

(i) tidak berlaku untuk jabatan publik yang dipilih (elected officials);

(ii) berlaku terbatas jangka waktunya hanya selama 5 (lima) tahun sejak terpidana selesai menjalani hukumannya

(iii) dikecualikan bagi mantan terpidana yang secara terbuka dan jujur mengemukakan kepada publik bahwa yang bersangkutan mantan terpidana

(iv) bukan sebagai pelaku kejahatan yang berulang-ulang

Dalam putusannya Mahkamah Konstitusi menyatakan bahwa pasal-pasal yang diajukan constitutional review tersebut yang tercantum dalam Undang-Undang Nomor 10 Tahun 2008 tentang Pemilihan Umum DPR, DPD dan DPRD dan pasal 58 huruf $\mathrm{f}$ Undang-Undang Nomor 12 Tahun 2008 tentang Perubahan Kedua Atas UndangUndang Nomor 32 Tahun 2004 tentang Pemerintahan Daerah dinyatakan bertentangan dengan UUD yakni pasal 27 ayat (1), pasal 28 C ayat (1), pasal 28 D ayat (1) dan ayat (3) dan tidak mempunyai kekuatan hukum yang mengikat sepanjang tidak memenuhi syarat (conditionally unconstitutional). Sebagaimana dijamin oleh Undang-Undang Dasar 1945 terutama pasal-pasal sebagai berikut: Pasal 27 ayat (1), Pasal 28c ayat (2), Pasal 28d ayat (1) dan Pasal 28d ayat (3). Dengan demikian apa yang telah diputuskan oleh MK telah sesuai dengan Konstitusi Negara Republik Indonesia yaitu UUD 1945.

\section{Analisis Terhadap Implikasi Putusan MK Nomor: 4/PUU-VII/2009}

Setelah putusan MK tersebut dibacakan dalam sidang pleno terbuka untuk umum pada tanggal 24 Maret 2009. Pada saat itulah pasal 12 huruf g dan pasal 50 ayat (1) huruf g Undang-Undang Nomor 10 Tahun 2008 tentang Pemilihan Umum DPR, DPRD dan DPD dan pasal 58 huruf f Undang-Undang Nomor 12 Tahun 2008 tentang Perubahan Kedua Atas Undang-Undang Nomor 32 Tahun 2004 tentang Pemerintahan Daerah dinyatakan inkonstitusional bersyarat dan tidak mempunyai kekuatan hukum yang mengikat.

Implikasi yang terjadi akibat Putusan Mahkamah Konstitusi Nomor: 4/PUUVII/2009 adalah berpengaruh terhadap posisi yuridis pasal-pasal yang diajukan constitutional review tersebut dan terhadap aspek politik, di mana MK membuka kesempatan bagi mantan narapidana untuk dapat menduduki jabatan publik yang dipilih (elected officials). 


\section{Berimplikasi Terhadap Posisi Yuridis Pasal-Pasal Yang Diajukan Constitutional Review terhadap UUD 1945}

Pada pasal yang diajukan constitutional review, ada pertentangan dengan UUD sebab norma hukum yang dicantumkan dalam pasal-pasal tersebut telah berbuat tidak adil, yakni telah mendiskriminasikan antara warga negara yang mantan narapidana dengan warga yang bukan mantan narapidana serta tidak memberikan kedudukan hukum yang sama dalam hukum dan pemerintahan. Dan inkonsisten dalam menetapkan persyaratan-persyaratan sehingga menimbulkan ketidakpastian hukum

Putusan MK Nomor: 4/PUU-VII/2009 berimplikasi pada posisi yuridis pasal 12 huruf g dan pasal 50 ayat (1) huruf g Undang-Undang Nomor 10 Tahun 2008 tentang Pemilihan Umum DPR, DPD dan DPRD dan pasal 58 huruf $\mathrm{f}$ Undang-Undang Nomor 12 Tahun 2008 tentang Perubahan Kedua Atas Undang-Undang Nomor 32 Tahun 2004 tentang Pemerintahan Daerah, yakni pasal-pasal tersebut bertentangan dengan UUD 1945 secara bersyarat karenanya tidak mempunyai kekuatan hukum yang mengikat sepanjang tidak memenuhi syarat-syarat tertentu. Syarat-syarat tersebut adalah:

1. Berlaku hanya untuk jabatan publik yang dipilih (elected official) yaitu pejabat yang dipilih melalui pemilu umum, dan sepanjang tidak dijatuhi pidana tambahan berupa pencabutan hak pilih oleh putusan pengadilan yang telah mempunyai kekuatan hukum tetap.

2. Berlaku terbatas jangka waktunya hanya selama 5 tahun sejak terpidana selesai menjalani hukumannya.

3. Dikecualikan bagi mantan terpidana yang secara terbuka dan jujur mengemukakan kepada publik bahwa yang bersangkutan mantan narapidana.

4. Bukan pelaku kejahatan yang berulang-ulang.

Jadi pasal 12 huruf g dan pasal 50 ayat (1) huruf g Undang-Undang Nomor 10 Tahun 2008 tentang Pemilihan Umum DPR, DPD dan DPRD dan pasal 58 huruf $\mathrm{f}$ Undang-Undang Nomor 12 Tahun 2008 tentang Perubahan Kedua Atas UndangUndang Nomor 32 Tahun 2004 tentang Pemerintahan Daerah tersebut tidak dapat diberlakukan lagi tanpa memenuhi syarat-syarat tersebut.

\section{Berimplikasi Terhadap Aspek Politik Bahwa Mantan Narapidana Dapat Menduduki Jabatan Publik Yang Dipilih (Elected officials)}

Selain berimplikasi pada posisi yuridis pasal 12 huruf g dan pasal 50 ayat (1) huruf g Undang-Undang Nomor 10 Tahun 2008 tentang Pemilihan Umum DPR, DPD dan DPRD dan pasal 58 huruf f Undang-Undang Nomor 12 Tahun 2008 tentang Perubahan Kedua Atas Undang-Undang Nomor 32 Tahun 2004 tentang Pemerintahan Daerah, pasca putusan MK Nomor:.4/ PUU.VII/ 2009 juga berimplikasi pada aspek politik yaitu dibukanya kesempatan bagi mantan narapidana untuk menduduki elected officials (jabatan publik yang dipilih). 
Dibukanya kesempatan kepada mantan narapidana dalam berpolitik berarti Mahkamah Konstitusi telah berbuat adil dan telah mengembalikan hak-haknya yang telah dirampas karena dulu pernah dipidana. Dalam konsep negara demokrasi semua warga negaranya mempunyai hak-hak yang harus dijamin, dihormati, dan dilindungi oleh pemerintah. Termasuk hak-hak mantan narapidana yang sudah bertaubat dia juga berhak untuk mendapatkan perlindungan, jaminan atas hak-hak asasi dari pemerintah.

Keputusan MK tersebut berimplikasi positif yang menggembirakan publik sebab hak mantan narapidana telah dikembalikan, yakni tidak adanya diskriminasi, adanya pengakuan dan penghormatan atas hak asasi manusia, nilai-nilai agama dan ketertiban umum dalam suatu masyarakat demokrasi sebagaimana yang diperintahkan oleh UUD 1945.

Putusan MK Nomor: 4/PUU-VII/2009 yang membolehkan mantan narapidana sebagai anggota legislatif, DPD dan kepala daerah dengan syarat-syarat tertentu, telah mengembalikan hak-hak rakyat yakni hak seorang mantan narapidanan untuk ikut berpartisipasi dalam politik dan hak yang sama dihadapan hukum. Sebab dia sudah bertaubat dan telah membayar semua kesalahannya di masa lalu yaitu dengan dipidana penjara.

Dengan adanya keputusan tersebut maka peluang mantan narapidana untuk mengikuti perebutan kursi Dewan Perwakilan Rakyat, menjadi calon Presiden atau Wakil Presiden serta Kepala Daerah terbuka lebar.

\section{KESIMPULAN}

Putusan Mahkamah Konstitusi nomor: 4/PUU-VII/2009 menyatakan mantan narapidana boleh mencalonkan sebagai anggota legislatif, DPD dan Kepala Daerah, asalkan memenuhi syarat-syarat yaitu:

1. Berlaku hanya untuk jabatan publik yang dipilih (elected official) yaitu pejabat yang dipilih melalui pemilu umum, dan sepanjang tidak dijatuhi pidana tambahan berupa pencabutan hak pilih oleh putusan pengadilan yang telah mempunyai kekuatan hukum tetap.

2. Berlaku terbatas jangka waktunya hanya selama 5 tahun sejak terpidana selesai menjalani hukumannya. Jadi telah melalui proses adaptasi kembali ke masyarakat sekurang-kurangnya selama 5 tahun setelah yang bersangkutan menjalani pidana penjara yang dijatuhkan oleh pengadilan yang telah mempunyai kekuatan hukum tetap.

3. Dikecualikan bagi mantan terpidana yang secara terbuka dan jujur mengemukakan kepada publik bahwa yang bersangkutan mantan narapidana.

4. Bukan pelaku kejahatan yang berulang-ulang. Penjahat residivis tentunya tidak mengenal kata taubat untuk merubah dirinya dan tujuan pemidanaan yang bersifat retributive (penebusan dosa) dan reformative (memperbaiki kembali para narapidana) tidak berhasil maka pelaku kejahatan yang berulang-ulang dengan persyaratan ini jelas tidak dapat dipilih sebagai pejabat publik yang dipilih. 
Mahkamah Konstitusi telah melakukan upaya hukum untuk melindungi dan mengembalikan hak-hak konstitusional warga negara (constitutional citizen's rights) yang terenggut akibat kehadiran undang-undang yang inkonstitusional; Pasca putusan Mahkamah Konstitusi Nomor: 4/PUU-VII/2009 berimplikasi pada posisi yuridis pasalpasal yang diajukan constitutional review: Karena bertentangan dengan UUD 1945 dan tidak mempunyai kekuatan hukum yang mengikat sepanjang tidak memenuhi syarat dan berimplikasi pada aspek politik yakni membuka kesempatan kepada mantan narapidana untuk dapat menduduki jabatan publik yang dipilih (elected officials) yaitu melalui pemilihan umum.

\section{Saran}

Dari kesimpulan di atas, penulis mengajukan beberapa saran, antara lain :

1. Dikarenakan posisi yuridis pasal 12 huruf g, pasal 50 ayat 1 huruf g UndangUndang Nomor 10 Tahun 2008 tentang Pemilihan Umum DPR, DPD dan DPRD dan pasal 58 huruf $\mathrm{f}$ Undang-Undang Nomor 12 Tahun 2008 tentang Perubahan Kedua Atas Undang-Undang Nomor 32 Tahun 2004 tentang Pemerintahan Daerah tidak mempunyai kekuatan hukum mengikat, maka penulis menyarankan kepada pembuat Undang-Undang dalam hal ini Pemerintah dan DPR untuk menyelaraskan dan/atau mengamandemen pasal-pasal yang terkait dalam Undang-Undang Nomor 10 Tahun 2008 tentang Pemilihan Umum DPR, DPD dan DPRD dan Undang-Undang Nomor 12 Tahun 2008 tentang Perubahan Kedua Atas Undang-Undang Nomor 32 Tahun 2004 tentang Pemerintahan Daerah sesuai keputusan Mahkamah Konstitusi nomor: 4/PUUVII/2009 Tanggal 28 Januari 2009.

2. Bagi pemerintah khususnya pembentuk Undang-Undang untuk menerapkan keputusan Mahkamah Konstitusi sebagai referensi dalam pembuatan kebijakankebijakan di masa mendatang agar tidak terjadi ketidakadilan dan ketidakpastian hukum bagi warga negara Indonesia.

\section{REFERENSI:}

\section{Buku}

Fathurrahman-dkk, 2004, Memahami Keberadaaan Mahkamah Konstitusi,

PT Citra Aditiya Bakti, Bandung.

Titik Triwulan Tutik, 2006, Pokok-Pokok Hukum Tata Negara Pasca Amandemen UUD 1945,

Prestasi Pustaka, Jakarta.

Peraturan Undang - Undang.

Undang-Undang Dasar 1945 Pasca Amandemen

Undang-Undang Nomor 24 Tahun 2003 Tentang Mahkamah Konstitusi

Undang-Undang Nomor 10 Tahun 2008 Tentang Pemilu DPR, DPD, dan DPRD

Undang-Undang Nomor 12 Tahun 2008 tentang Perubahan Kedua Atas UndangUndang Nomor 32 Tahun 2004 tentang Pemerintahan Daerah 